\title{
The Fate of An Idea Whose Time Has Come: Antidiscrimination Law in the Second Decade after Brown v. Board of Education
}

\author{
Owen $M$. Fisst
}

The import of Brown $v$. Board of Education ${ }^{i}$ is not confined to school segregation. Its more general significance stems from its relationship to the idea that racial discrimination is wrong and should be outlawed. Although the idea had been advanced and debated before 1954, Brown gave it a special prominence and a special legitimacy. In a sense, it set the idea loose.

The idea became the organizing principle of a civil rights movement. By early 1964, at the end of the first decade following Brown, the movement had gained considerable momentum, and its ultimate victory seemed assured. Congress had before it a civil rights bill that seemed more momentous than other post-Brown civil rights laws (the Givil Rights Acts of 1957 and 1960 being limited to voting discrimination). Public interest in the bill was unusually high due to a series of tumultuous events-the sit-ins, the March on Washington in August, 1963, and the assassination of President Kennedy, who had been identified with the civil rights movement and was the original sponsor of the legislation. The bill received the support of President Johnson and the Northern Democrats. But passage of the bill still required Republican votes to offset the opposition of southern Democrats. Then, on May 19, 1964, Senator Everett McKinley Dirksen, the Republican leader from Illinois, announced that he too was throwing his support behind the bill that he had long resisted. In his typically dramatic fashion, he borrowed a line from Victor Hugo: "No army is stronger than an idea whose time has come."' This announcement made enactment of the bill a virtual certainty, and on July 2, the Civil Rights Act of 1964 became law.

That occasion marked the end of one era-the idea set loose in Brown a decade earlier had indeed arrived-and the beginning of anotherthe one that is the focus of this essay. My concern is with this second post-Brown decade-more particularly, with the changes that the period

† Professor of Law, Yale University.

1347 U.S. 483 (1954).

2 N.Y. Times, May 20, 1964, at 1, col. 7. 
1964-1974 worked in the federal antidiscrimination laws-in extending their reach, in devising new techniques to enforce them, and in interpreting the obligations they impose. My intent is to identify and explain the principal changes of the second decade, not for the purpose of hailing all of thein as "progress," but rather as a first step toward defining our present position.

\section{EXtending the REAch of the LAw}

\section{A. The Quiescence of the Coverage Question}

One of the most striking features of the second post-Brown decade is the waning of the state action debate that dominated the first decade. That debate concerned the reach of federal antidiscrimination lawwhat discriminatory activities should be prohibited by federal law?

The state action issue was debated on two levels. At the first level, debate centered on an attempt to persuade the courts that the equal protection clause reached activities that had traditionally been regarded as private. This effort was understandable, since the equal protection clause was practically the only general national antidiscrimination law available; at the same time, the words of the clause seemed to limit its reach to state activities. Little attention was paid to the thirteenth amendment, and the Reconstruction civil rights acts did not appear particularly promising, since the courts had read state action requirements into thein as well.

At another level, the state action debate involved the question of whether Congress had the constitutional power to prohibit private discrimination. The assumption was that Congressional action would have to be predicated on section five of the fourteenth amendment. Since that provision was merely a grant of power to enforce the substantive provisions of the amendment, it too was considered limited by the state action requirement of the equal protection clause. This level of the debate seemed less pressing, however, because it was not clear that Congress had the will to exercise this argued-for power; at any rate, it seemed conceivable that antidiscrimination legislation could be predicated on alternative sources of power not limited by a state action requirement, such as the commerce clause.

The intensity of the state action debate was only in small part a function of the wording of the fourteenth amendment; more important, three clashes of basic values energized the debate. The first concerned the wronguess of private discrimination and the appropriateness of legal intervention. By 1963-1964 there was some consensus that it was wrong for a government to discriminate on the basis of race-for em- 
ployees of a state enterprise to refuse to serve an individual because of his race or for a school board to assign students on a racially segregated basis. It also seemed appropriate for the law to intervene in these instances. To be sure, Professor Wechsler had written a troubling analysis of Brown v. Board of Education, underscoring the relationship between the dual school system and private associational preferences, and pointing to the difficulty of formulating a neutral principle that required the subordination of those preferences. ${ }^{3}$ But his analysis did not shatter the consensus. It only posed an intellectual puzzle; there was faith that somehow the neutral principle would be discovered.

There was no comparable consensus concerning the wrongness of private discrimination or the role the law should take in this conflict between liberty and equality. Many were prepared to allow a private employer or place of accommodation to cater to its customers' preferences not to associate with Blacks. The absence of a consensus accounted, in part, for the controversial quality of the grand state action cases, such as Shelley v. Kraemer ${ }^{4}$ and Burton v. Wilmington Parking Authority. ${ }^{5}$ In those cases, the Court displayed great ingenuity in discovering government involvement in what appeared to be private activities. But the Court did not find that a government official had been discriminating, and thus doubt remained as to both the wrongness of the prohibited conduct and the appropriateness of legal intervention.

Second, the state action debate reflected controversies over the role of national law in a federal system. The assumption of the debate was that the equal protection clause invalidated discriminatory state laws, and in that sense the supremacy of federal law was unquestioned. But deep questions persisted. One arose from the view that no national law - whether constitutional or statutory-should regulate relationships between individuals, a task more appropriately left to the states. This view had great currency in the early 1960s, when the states were viewed as the primary source of "police regulations." The demand for an exertion of national power was usually premised on the theory that the states had defaulted, and this theory implicitly acknowledged the traditional primacy of the states in this area.

The demand for a national antidiscrimination law also challenged traditional ideals of local or regional autonomy. It was clear that if the judiciary were to extend the equal protection clause to private activity, or if the national legislature were to enact an antidiscrimination law,

3 Wechsler, Towards Neutral Principles of Constitutional Law, 73 HARv. L. REv. 1, 3134 (1959).

4334 U.S. 1 (1948).

5365 U.S. 715 (1961). 
it would be imposing the views of one region of the country upon another. Indeed, that was one of the purposes of national law in this domain. The threat to the ideal of home rule was mitigated, however, by the fact that the prime beneficiaries of the proposed national law were at that time excluded from the franchise in those regions.

Third, the state action debate involved a controversy over the institutional competence of the judiciary. Whenever the courts were urged to extend the equal protection clause to private activity, it was argued in reply that this radical move should not be made by the judiciary, the nonrepresentative branch of government. That much judicial expansion of the clause's coverage would be inconsistent with our democratic ideals, so the argument ran, and would jeopardize the prestige of the Court.

Moreover, a judicial fiat was likely to be ineffective. Enforcement would be totally dependent on case-by-case litigation by individual victims, without the moral and financial support that a statutory enactment could provide. The force of this argument could hardly be denied, particularly since Shelley $v$. Kraemer was the chief exhibit. Shelley had brought the enforcement of racially restrictive covenants within the reach of the equal protection clause in 1948, and yet during the next decade and a half it had barely reduced the use of these covenants. Indeed, the activist's response to the argument was often a form of confession and avoidance-the Court was the last resort.

These were the concerns that gave life to the state action debate, a debate that seemed to be rushing towards a climax as the October, 1963 Term of the Supreme Court began. In Bell v. Maryland, ${ }^{\circ}$ the Court once again had a sit-in case before it. Blacks had demanded nondiscriminatory service from a privately owned restaurant in Maryland; service had predictably been refused; and, when the Blacks had refused to leave, they had been arrested and prosecuted for criminal trespass. There appeared to be five Justices who, if a decision had to be made, would conclude that there was sufficient state action to bring the equal protection clause into play-a decision that would virtually abrogate the state action requirement and make the equal protection clause a nationwide, comprehensive antidiscrimination law. It also appeared that the Court had available none of the procedural devices it had previously used to reverse sit-in convictions while avoiding this momentous constitutional step.

Two events in the spring of 1964 made it feasible for the Court to avoid the constitutional issue. First, Justice Brennan, with his usual in- 
genuity, saw an avoidance technique in the Maryland legislature's recent passage of an antidiscrimination law. The Court could reverse and remand to see whether the new law would be applied to the previous convictions. Second, there was Senator Dirksen's announcement. It was clear that Congress was about to pass a civil rights law that would reach private activities, including places of public accommodation. This statute would achieve the desired result and coverage, and at the same time (since it would be founded on the commerce clause) circumvent an interpretation of the equal protection clause that would obliterate the distinction between private and governmental activity. An expansive interpretation of the fourteenth amendment would be a radical conception and difficult to defend. Moreover, the Justices were aware of their own institutional limitations. Accordingly, on June 22, 1964, just a month after Senator Dirksen's speech, the Court chose not to attempt to resolve the state action debate. Instead, it turned to the national legislature to establish the extended coverage.

This extension occurred in three distinct stages. The first, which marked the end of the first post-Brown decade, was the enactment of the Givil Rights Act of $1964 .{ }^{7}$ That statute imposed an antidiscrimination prohibition on public accommodations, private employment, and all private enterprises (such as private hospitals and private universities) receiving federal financial assistance. The Act was a massive assault on private discrimination. But housing, a significant area of private activity, remained unaffected. Four years later, well into the second decade, the national legislature took its second step, in the Civil Rights Act of 1968,8 by extending the antidiscrimination laws to private housing. After this, there seemed little left to do; yet, to the surprise of all, the judiciary re-entered the picture and, as a third step, resuscitated century-old civil rights statutes, sections 1981 and 1982 of title 42 of the United States Code, by overruling cases that had construed these statutes to cover state action only. ${ }^{9}$

These measures did not resolve the constitutional state action debate - they only mooted it. ${ }^{10}$ Today, federal antidiscrimination laws cover

742 U.S.C. $\$ \S 1971$, 1975a-e, 2000a-h (1970) (originally enacted as Act of July 2, 1964, Pub. L. No. 88-352, 78 Stat. 241).

842 U.S.C. $\$ \$ 1973 \mathrm{j}, 3601-3610,3631$ (1970) (originally enacted as Act of Apr. 11, 1968, Pub. L. No. 90-284, 82 Stat. 73).

9 See, e.g., Jones v. Alfred H. Mayer Co., 392 U.S. 409 (1968) (construing section 1982); Boudreaux v. Baton Rouge Marine Contracting Co., 437 F.2d 1101 (5th Cir. 1971) (construing section 1981); Waters v. Wisconsin Steel Works of Int'1 Harvester Co., 427 F.2d 476 (7th Cir. 1970) (same).

10 From time to time the issue flares up in other contexts, for example, in cases involving evictions by landlords retaliating against tenants who have reported building code 
most private busmess activity. Private clubs, small employers, Mrs. Murphy's rooming house, and private schools not receiving federal financial assistance may still be exempt. But these zones of private discrimination are under attack, ${ }^{11}$ and, in any event, are only marginal. The basic coverage is nearly total, and that fact is evidence not only of the pervasiveness of national police power, but also of a national consensus that private discrimination is wrong and an appropriate subject for legal regulation. The extended coverage is the most distinctive hallmark of the second decade.

Although statutes made it unnecessary to extend the equal protection clause itself, the question remained whether Congress had the authority to enact measures to reach private discrimination. An equally broad Congressional response to discrimination during Reconstruction had been vitiated by the Civil Rights Cases, where the Court had cut remedial statutes back to reach only state discrimination.12 But this time around the statutes were all sustained in their broadest reach and, interestingly, in a manner that did not reactivate the state action debate. No one wanted to return to the issue left dangling in Bell $v$. Maryland..$^{13}$

The legislators enacted the public accommodations provisions of the Civil Rights Act of 1964 as an exercise of the commerce power, and the Court was willing to accept the propriety of that action at face valueeven to the point of holding that Ollie's Barbecue was within their reach. ${ }^{14}$ The fair employment provision was also a commerce measure, and, after the public accommodations provisions were sustained in this broad fashion, there was little doubt about its constitutionality.

The legislators were hesitant to use the commerce power as a foundation for the fair housing law. Instead, they relied on section five of the fourteenth amendment, which had been liberally construed two years

violations. See Edwards v. Habib, 397 F.2d 687 (D.C. Gir. 1968); Aluli v. Trusdell, 54 Hawaii 417, 508 P.2d 1217, cert. denied, 414 U.S. 1040 (1973).

11 See, e.g., Gonzales v. Fairfax-Brewster School, Inc., 363 F. Supp. 1200 (E.D. Va. 1973) (segregation at private school violates section 1981); McGlotten v. Connally, 338 F. Supp. 448 (D.D.C. 1972) (three-judge court) (tax exemption for private club violates equal protection guarantees of Constitution); Equal Employment Opportunity Act of 1972, 42 U.S.C. § $2000 \mathrm{e}$ (b) (Supp. 1974), amending 42 U.S.C. $\$ 2000 \mathrm{e}$ (a) (1970) (reducing minimum number of employees from twenty-five to fifteen in definition of "employer").

12109 U.S. 3 (1883).

13 In Hamm v. City of Rock Hill, 379 U.S. 306 (1964), another sit-in case, the Court relied on the 1964 Act to overturn the convictions. This maneuver was plainly another device to side-step the constitutional issue, since both the sit-ins and the convictions had occurred before the Act was passed.

14 Katzenbach v. McClung, 379 U.S. 294 (1964); see Heart of Atlanta Motel v. United States, 379 U.S. 241 (1964). 
earlier in Katzenbach $v$. Morgan.15 Under Morgan, Congress has the power to find and remedy violations of the equal protection clause in situations to which the Court has not yet spoken. The case also pointed to a relationship between residential segregation and governmental discrimination that would permit Congress to conclude that the state action requirement was sufficiently satisfied to warrant a fair housing law.

But the problem of finding an equal protection foundation for the fair housing law never came to a head. Immediately after the passage of that law, the Court overruled earlier cases that had construed section 1982-a Reconstruction statute aimed at property rights-to require state action. The new decision, Jones $v$. Alfred $H$. Mayer Co., ${ }^{16}$ transformed section 1982 into a national fair housing law as broad, if not broader, than the one just passed by Congress. ${ }^{17}$ Then, well aware of the significance of its decision for the recently enacted law, the Court sustained the newly expanded section 1982 under the thirteenth amendment, which does not have a state action requirement. ${ }^{18}$

In short, the second decade is marked not only by the quiescence of the state action debate, but also, perhaps more important, by judicial determination to keep it quiescent.

\section{B. The Proliferation of the Protectorate}

While federal protections against discrimination were reaching more and more spheres of activity, a complementary expansion of the law was in progress. The past decade has seen a proliferation of the beneficiaries of the antidiscrimination laws.

Antidiscrimination laws generally operate by prohibiting discrimination on the basis of certain criteria, which in turn identify or delin-

15 384U.S. 641 (1966). See Cox, Foreword: Constitutional Adjudication and the Promotion of Human Rights, 80 HARv. L. REv. 91, 102, 117-18 (1966).

16392 U.S. 409 (1968).

17 The field of labor law offers another example of how courts have read guarantees against private discrimination into an old statute, thus providing an alternative theory with which citizens can attack practices that are outlawed by recent civil rights legislation. In Local 12, United Rubber Workers v. NLRB, 368 F.2d 12 (5th Cir. 1966), cert. denied, 389 U.S. 837 (1967), the court held that racial discrimination by a union against its members is an unfair labor practice within the meaning of section $8(b)(1)(A)$ of the National Labor Relations Act, 29 U.S.C. \& 158(b)(1)(A) (1970). The practical result was to give workers another forum-the NLRB-for seeking relief from the discriminatory practices outlawed by Title VII. Employer discrimination was brought within the same statute in United Packinghouse Workers Union v. NLRB, 416 F.2d 1126 (D.C. Cir.), cert. denied, 396 U.S. 903 (1969).

18392 U.S. at 439. 
eate the groups that are protected by the law. ${ }^{10}$ Laws against racial discrimination, for example, are not directed at a particular group, such as Blacks, but simply make "color" a forbidden criterion. For that reason, it might seem that all racial groups are intended beneficiarieseven the dominant group, Whites. This impression is misleading, however, because it ignores a distinction between the primary and the formal beneficiaries of these laws. The class of primary beneficiaries is not the entire class of persons who theoretically could be adversely affected by decisions based on the forbidden criterion, and who thus could claim formal entitlement to protection. Rather, primary beneficiaries are those who are likely to be adversely affected and are thus thought to need the law's protection. The legislation was primarily directed at their needs. A phrase such as "any color" has never, in my judgment, been intended to deny that there is a primary group of beneficiaries, such as Blacks or other racial minorities. Rather, it has been used to give the law a facial neutrality that in turn reflects considerations of politics or fairness. Legislators must tell their constituents that a law prohibiting racial discrimination will protect everyone, including Whites.

At the outset of the decade, Blacks were generally viewed as the exclusive primary beneficiaries of the antidiscrimination laws. No one denied that other groups were within the law's protection or that there was reason to believe they were the victims of widespread discrimination. But little attention-legal or public - was paid to whatever claims those groups made. Indeed, there was some suspicion that the inclusion of other groups within the statutes-for example, the successful attempt to bring women within the reach of Title VII of the Civil Rights Act of 1964-had been intended as an act of political sabotage. Now, with the coverage question quiescent, the beneficiary question is more prominent. Blacks have to share center stage with other groups.

What other groups are included in the class of primary beneficiaries? There are, of course, the traditional allies-the other racial groups and the religious and ethnic minorities. ${ }^{20}$ They usually can claim the benefits of the same laws that protect Blacks. In addition, there are two

10 Some antidiscrimination laws, for example, the federal civil rights statutes of the past decade and the fifteenth amendment, specify the criteria forbidden to decision makers. Thus, the groups that will be protected are unambiguously determined. The equal protection clause is more broadly worded, however, and the groups of beneficiaries are defined through a two-step interpretative process: the first step is the interpretation of the clause to prohibit discrimination or distinction based on "invidious" or "arbitrary" criteria; the secoud is judicial specification of the criteria.

20 One example is the growing attention to the welfare of Indians. 
groups of primary beneficiaries whose relationship to antidiscrimination law is more noteworthy.

One consists of women-a group that is not a minority and whose members generally have an intimate personal relationship with the alleged oppressors that members of other victim groups do not have with their respective alleged oppressors. ${ }^{21}$ In some cases, special legislation has been needed to bring this group within the reach of the antidiscrimination laws. For example, Title IX of the Higher Education Act recently filled the gap left by Title VI of the Civil Rights Act of 1964..22 The proposed Equal Rights Amendment could be viewed either as a new constitutional rule or as an attempt to spell out and emphasize a protection implicit in the equal protection clause.

In other instances, it has been a matter of activating existing machinery. Certain laws enacted at the outset of the decade, such as Title VII, formally included women within their protection but were dormant for most of the period; for example, although the Department of Justice began its litigation program against racial discrimination in employment in 1966, it filed no sex discrimination suits until 1970. In more recent years, substantial resources have been committed to enforcing these laws on behalf of women.

The other notable group of primary beneficiaries to emerge over the decade is the poor. The inclusion of this group within the protection of an antidiscrimination law, the equal protection clause, has been a more unusual doctrinal step than the inclusion of any other group. The class is less well defined than other victim classes and, however defined, its membership theoretically can change. Furthermore, the wrongfulness of wealth discrimination is more problematic. In a market economy, a certain amount of wealth discrimination is arguably a positive good, a technique for facilitating vertical mobility and increasing productivity. Finally, the poor do not have a legacy of explicit discrimination against them. Almost the only laws subjected to attack have been certain unitary rules that are applicable to all but that place a heavier burden on the poor than on the rich. It has been claimed that they work a

21 Another set of beneficiary groups defined by demographic lines would be the age groups. They receive protection, for example, under the Age Discrimination in Employment Act of 1967, 29 U.S.C. \$§ 621-634 (1970), which prohibits job discrimination against workers between forty and sixty-five years of age; and under the twenty-sixth amendment, which guarantees to eighteen-year-olds the right to vote. The young and the aged also differ sharply from the traditional victim groups, because everyone in the dominant group has been, or anticipates being, a member of the allegedly victimized class.

2220 U.S.C. §§ 1681-1686 (Supp. 1972). Title VI applies only when discrimination in federally funded programs is on the basis of race, color, or national origin. 42 U.S.C. $\S 2000 \mathrm{~d}(1970)$. 
"discrimination" against the poor, although on their face there is no discrimination.

Despite these theoretical difficulties, discrimination against the poor received almost as much attention in the latter part of the decade as discrimination against Blacks. This protectionist doctrine for the poor may have had its roots in Griffin $v$. Illinois, ${ }^{23}$ a decision of the late 1950s, and may have received a political push from the War on Poverty in the mid-1960s. But, like protection for women, it flourished primarily in the late 1960s, in the wake of the favorable response to the claim against racial discrimination, especially as courts began to develop analytic tools for perceiving how a rule that seemingly applies to both Whites and Blacks can be a form of racial discrimination.

More important, the race cases ignited aspirations of equality and deepened society's commitunent to the antidiscrimination principle. Once armed with that principle, it was natural to use the principle on behalf of another group. And given the double membership phenomenon-most Blacks are poor-it was natural to choose the poor as a group deserving the protection afforded by the antidiscrimination principle. At the very least, this extension would protect the Blacks, and the protection conferred on others would be a sort of bonus.

Harper v. Virginia Board of Elections, ${ }^{24}$ the poll tax case, was striking testimony to the intimate relationship between the success of the Blacks and the emergence of the poor as a new protectorate. Perhaps even more than Griffin v. Illinois, it gave life and energy to the doctrine construing the equal protection clause as an antidiscrimination law for the protection of the poor. Yet, at the same time, Harper was the culmination of a more than thirty year struggle to outlaw a tax that was universally perceived as an instrument of Black disenfranchisement.

The emergence of other groups demanding protection under the antidiscrimination laws has had great significance for Blacks, the principal claimants at the outset of the decade. To the extent that Blacks fit within one of the other victim groups-such as the poor-they benefit from the protection afforded that group, though in a diffuse and indirect way: although most Blacks are poor, most poor are not Black. But where the overlap is more limited-as with Blacks vis-à-vis religious minorities or women-the relationship between Blacks and the other viction group is potentially antagonistic. Blacks must now compete with these groups for public attention, for the legislature's concern, and for law enforcement resources-all of which are bounded by conditions of 
scarcity. In addition, they must compete for economic and educational opportunities that are undoubtedly scarce. If Blacks obtain a larger slice of the pie, for example, a job in industry or a place at a university, it may well be at the expense of another group protected by the antidiscrimination laws, for example, women or Jews, rather than the socalled dominant group, the White-male-Protestant class.

We are also beginning to understand that some of the doctrinal positions advanced by Blacks may work against the interests of other protected groups, and vice versa. Blacks have exerted great pressure to do away with objective criteria, for example, test scores for hiring and admissions, and to substitute more subjective selection procedures. It is argued that traditional objective criteria have an inherent cultural bias or that they perpetuate the disabilities imposed on Blacks in the past. But other beneficiary groups, such as women or Jews, often find it to their advantage to insist upon rigorous application of these objective criteria, which do not disable them and indeed might provide the only safeguard against discrimination. Such doctrinal antagonism is bound to result when all the victin groups, despite their special social histories, are obliged to live within the same house-within an antidiscrimination law.

\section{InNovation IN LAW ENFORCEMENT MeTHODS}

The civil rights area has been constantly plagued by uncertainties about law enforcement techniques. Indeed, for many years it was argued-presumably with some sincerity-that there was no role for legal coercion in the area. The argument was that the predominant, if not exclusive, tools should be education, mediation, and conciliation (at least where no acts of violence have been committed). This view, reflected in the maxim that law cannot change the hearts of men, was prevalent in the years following World War II, and traces of it cropped up in those provisions of the Civil Rights Act of 1964 establishing the Community Relations Service ${ }^{25}$ and confining the Equal Employment Opportunity Commission (EEOC) to mediation. ${ }^{26}$ But these provisions were vestiges of another era. By the early 1960s there was a substantial commitment to traditional law enforcement techniques-imposing legal obligations and taking coercive steps to insure compliance. The goal of equality was more firmly entrenched. It was also understood that the first task was to change people's behavior, not their hearts, and that in any event law enforcement through coercion can be an educative device.

2542 U.S.C. \$ 2000g (1970). The Community Relations Service was transferred to the Department of Justice by Reorganization Plan No. 1 of 1966, 31 Fed. Reg. 6187 (1966).

2642 U.S.C. $\$ 2000 \mathrm{e}-5(\mathrm{~b})(1970)$. 


\section{A. Within the Courthouse}

At the beginning of the second decade, the paradigmatic law enforcement technique on the federal level was the private lawsuit for injunctive relief. This technique had deep historical roots. Particularly in school desegregation cases, however, two important variations from the classical model had been introduced-variations that illuminate subsequent modifications.

First, an institutional litigator, the NAACP Legal Defense Fund, was in control of the case. The naming of an individual as plaintiff was basically a concession to tradition; the named private plaintiff played little role in financing the lawsuit, participating in the strategic choices, or specifying the relief. Second, the remedy sought was of an unusual nature. Plaintiffs were usually not seeking an injunction to stop a discrete, easily defined act, comparable to an injunction against dumping waste into a river. Instead, they were trying to bring about rather ill-defined structural changes-for example, converting a "dual school system" into a "nonracial, unitary school system." As a result, use of the contempt power was infrequent; the motion for supplementary relief emerged as the principal device for coping with violations of a previous decree. The ambitious quality of relief sought also gave rise to the "planning" concept: the initial decree did not prescribe the defendant's conduct but only required him to submit a plan (to be embodied in a second decree), detailing what remedial action he proposed to take.

There were even further departures from the classical model in the course of the decade. First, the institutional litigator's role as a private attorney general acquired further legitimacy. This was accomplished, in part, by judicial doctrine that insulated the NAACP from hostile attacks. ${ }^{27}$ It was also fostered by rules, established legislatively and judicially, that enabled a victorious plaintiff in a racial discrimination suit to collect attorneys' fees as a matter of course, contrary to the usual American practice. ${ }^{28}$ In addition, both the federal government and charitable foundations made efforts, primarily through grant programs, to spur the growth of institutional litigators, who devoted some of their energies to the enforcement of antidiscrimination laws.

Second, the Department of Justice acquired statutory authority to advance antidiscrimination claims in the name of the United States. During the second decade, the Department emerged as one of the principal civil rights litigators-first and foremost on behalf of Blacks, but also on behalf of other racial and ethnic minorities and, in the employ-

27 See NAACP v. Button, 371 U.S. 415 (1963); NAAGP v. Alabama, 357 U.S. 449 (1958). 28 See Newman v. Piggie Park Enterprises, Inc., 390 U.S. 400 (1968). 
ment area, women. This development had roots in the Civil Rights Acts of 1957 and 1960, but in those statutes the grant of authority had been limited to voting litigation. During the early 1960 s the Department had also become involved in other areas, such as public education ${ }^{29}$ and public accommodations, ${ }^{30}$ but because it had brought suit or intervened without statutory authority, these efforts were sporadic and limited in their impact-hardly a litigation program.

In contrast, the Civil Rights Act of 1964 gave the Department broad statutory authority to sue to eliminate discrimination in public accommodations, public schools, state facilities, and employment. A litigation program beyond the voting area was launched, first emphasizing public accommodations, then schools, and finally, starting in 1967, employment. By 1968 the role of the Department in civil rights litigation was so well established that it seemed perfectly natural to give it a similar role in the enforcement of the newly enacted fair housing law.

The Department brought considerable resources and a special credibility to all these areas. Federal judges attached great weight to whatever the attorneys of the Department of Justice said, partly because of the traditional relationship between the federal judiciary and the Department, and partly because the Department was speaking not only for the alleged victims, but also for the United States. The victories were of considerable import, but they are not the exclusive measure of success; the very participation of the Department tended to attract public attention to the litigation. Furthermore, the Department's actions in court tended to deepen and solidify the Executive's commitment to equality. In some sense, high Executive officials were educated by and locked into the positions that the Department attorneys-the professionals-took for the United States in civil rights litigation. Those positions could on occasion be abandoned or repudiated, but only with a good explanation.

Third, there was a broader and more sophisticated use of judicial remedies than there had been in the first decade. Plaintiffs no longer

29 In some of these cases, the Department entered the picture because a federal installation, such as an army base, was implicated. See United States v. Madison County Bd. of Educ., 326 F.2d 237 (5th Cir.), cert. denied, 379 U.S. 929 (1964) (suit by Department of Justice dismissed), aff'g 219 F. Supp. 60 (N.D. Ala. 1963) and United States v. Biloxi Mun. School Dist., 219 F. Supp. 691 (S.D. Miss. 1963); United States v. County School Bd. of Prince George County, Virginia, 221 F. Supp. 93 (E.D. Va. 1963) (relief granted). In others, it did so because it perceived a threat to the integrity of the federal court system and the administration of justice. See, e.g., United States v. Barnett, 376 U.S. 681 (1964); Faubus v. United States, 254 F.2d 797 (8th Cir. 1958); Lee v. Macon County Bd. of Educ., 231 F. Supp. 743 (M.D. Ala. 1964).

30 United States v. City of Jackson, 318 F.2d 1 (5th Cir. 1963). 
relied almost exclusively upon the injunction; they sought a damage remedy more frequently, with occasional spectacular results. ${ }^{31}$ Moreover, the killing of three civil rights workers in Neshoba County, Mississippi, in June, 1964, sparked a reallocation of the resources of the Federal Bureau of Investigation and, as the decade progressed, a sizable increase in the number of criminal prosecutions for forceful interference with the exercise of civil rights. ${ }^{32}$ These efforts were buttressed by the enactment of Title I of the Civil Rights Act of 1968,33 which, relying on the concurring and dissenting opinions in United States $v$. Guest $^{34}$ (together amounting to a majority), established criminal penalties for private interference with fourteenth amendment rights, such as the right to go to a desegregated public school.

Plaintiffs also learned to make more effective use of the injunction. By 1967 the bankruptcy of the planning concept was acknowledged, and the plaintiffs and courts, with assistance from the Department of Health, Education, and Welfare (HEW), began writing desegregation plans for recalcitrant school boards. ${ }^{35}$ The judiciary turned away from the vague, open-ended injunctions of the early 1960s and insisted upon increasingly greater specificity. When freedom of choice was allowed, for example, the courts specified every last detail, such as the wording of the notices, the date of mailing, what to do once the school was filled to capacity, and so forth. Other procedural innovations, such as the statewide lawsuit, ${ }^{36}$ were initiated in order to avoid the necessity of bringing a series of individual lawsuits, one against each school district in the state-the practice that had prevailed at the outset of the decade.

All of these changes in law enforcement techniques were siguificant, but they were not radical departures from the classic litigation model. They were essentially adjustments within the traditional frameworkmeasures to improve the litigation model. It should also be noted that Congress, in the course of the decade, refused to institute one change that would have amounted to a significant departure from the litigation

31 One example is the four million dollar punitive damage award obtained by Professor Gould in an employment discrimination suit. Stamps v. Detroit Edison Co., 365 F. Supp. 87 (E.D. Mich. 1973).

32 Before fiscal year 1964 (July I, 1963 to June 30, 1964) the Civil Rights Division of the Department of Justice never filed more than twenty new criminal cases in a single fiscal year. 1963 ATT'Y GEN. ANN. REP. 192. The figure rose to twenty-nine in fiscal year 1969, fifty-one in fiscal year 1970, and fifty in fiscal year 1971. 1971 ATt'y GEN. ANN. REP. 60.

3342 U.S.C. \& $1973(j)$ (1970).

34383 U.S. 745, 762 (1966) (Clark, J., concurring); id. at 774-75 (Brennan, J., dissenting).

35 See, e.g., United States v. Jefferson County Bd. of Educ., 372 F.2d 836 (5th Cir. 1966).

36 See, e.g., Lee v. Macon County Bd. of Educ., 267 F. Supp. 458 (M.D. Ala. 1967), aff'd sub nom. Wallace v. United States, 389 U.S. 215 (1967). 
mold. Throughout the 1960s, there was a debate as to whether Congress should revive the law enforcement model that dominated the New Deal reforms by giving the federal fair employment agency, the EEOC, ceaseand-desist powers. In 1972 Congress chose not to duplicate the model of the 1930s (a model adopted by some states) and instead gave the EEOC the authority to sue in court. ${ }^{37}$ This outcome could be viewed as a decision to withhold effective law enforcement techniques from the EEOG, but many of those who have consistently supported strong enforcement of the law also supported this legislative decision. ${ }^{38}$ It is possible, therefore, that this particular legislative choice instead reflects doubts as to the effectiveness of the New Deal model, at least in the antidiscrimination area.

\section{B. Beyond the Courthouse}

1. Fund Termination. Although the legislative decision on the EEOC tended to reinforce the hegemony of the litigation model, there were two radical departures from that model during the second decade. One was the creation of the fund termination sanction: cutting off government grants and contracts to discriminators. Fund termination was first viewed not as a sword, but as a shield against government participation in discriminatory activities. ${ }^{39}$ But soon-due in part to a series of coincidences, such as the appointment of Secretary Gardner and the post1964 growth of the federal assistance programs in education and healthTitle VI evolved into an affirmative tool for eliminating discrimination.

This approach began as a strategy to obtain promises not to discriminate from the $\mathbf{2 0 0 0}$ hard-core districts that were still operating in open defiance of Brown in 1965. Judicial decisions holding that the HEW school desegregation standards were the minimum constitutional standards and that questionable procedures employed by HEW were valid $^{40}$ helped to make the initial ventures successful. These successes prompted an expanded effort, and in 1972 Title VI was supplemented by a provision that-would reach sex discrimination by government grantees.

The heavy use of Title VI by HEW starting in 1965, and the Department of Justice's employment litigation program starting in 1967, energized another component of the fund termination sanction-the

3742 U.S.C. $\$ 2000 \mathrm{e}-5(\mathrm{f})$, (i) (Supp. 1974). This statute also ended the authority for employment discrimination suits by the Department of Justice.

38 See, e.g., A. Blumrosen, BLACK EMployment AND the LAW 3-8 (1971).

39 See Simkins v. Moses H. Cone Mem. Hosp., 323 F.2d 959 (4th Cir. 1963).

40 United States v. Jefferson County Bd. of Educ., 372 F.2d 836 (5th Cir. 1966); Alabama NAACP State Conference of Branches v. Wallace, 269 F. Supp. 346 (M.D. Ala. 1967). 
President's Executive Order authorizing a fund termination sanction against government contractors. ${ }^{41}$ This portion of the fund termination sanction had predated Title VI but had lain dormant for years. Tough enforcement of the Executive Order did not come until the latter part of the decade, with the institution of the Philadelphia Plan in 1969.42 Taken together, Title VI and the President's Executive Order constituted the basis for a new legal sanction, fund termination, which today occupies a position as significant as that of litigation in the enforcement of antidiscrimination laws. ${ }^{43}$

At first blush, it may seem that the fund termination sanction is only an extension of the classical damage award, not a radical innovation in law enforcement. I believe, however, that the sanction carries a special coerciveness. This quality stems, in part, from a shift in the burden of going forward and the burden of persuasion. With new grants (a common phenomenon, since a large proportion of the grant programs postdate Title VI), with awards of contracts, and with renewals of grants, the applicant must come to the funding agency and demonstrate the absence of discrimination. In the damage action, on the other hand, the victim must prove the discrimination charge.

The special coerciveness is also the result of a consolidation of functions-the agency that decides whether to award the grant or contract is also the one that determines whether the applicant is discriminating. As a practical matter, this consolidation of functions tends to prevent the applicant from developing an antagonistic relationship with the adjudicator, which often occurs in the courtrooin when a litigant fully asserts his rights. The applicant may have the option of demanding a hearing before an impartial hearing officer (with the outcome reviewable by the Secretary) or of obtaining judicial review of a denial. But the burdens of time and money that operate as a barrier to the plaintiffvictim in the traditional lawsuit work to the detriment of the defendant-discriminator under the fund termination sanction. The defendant-discriminator is likely to submit to the demands of the agency in the initial application for money, to avoid a controversy.

Finally, the special coerciveness of the fund termination sanction may be a product of the magnitude of the potential loss. The amount of money at stake is not confined to the amount necessary to compensate for the damage caused by the discrimination but often includes the en-

41 Exec. Order No. 11,246, 3 C.F.R. 339, 344 (Comp. 1964-65).

42 See Comment, The Philadelphia Plan: A Study in the Dynamics of Executive Power, 39 U. CH. L. REv. 723 (1972).

43 See also Adams v. Richardson, 480 F.2d 1159 (D.C. Cir. 1973), a successful private action to compel HEW to enforce Title VI more vigorously. 
tire sum the applicant now obtains or is seeking to obtain from the government.4 If an enterprise takes anything from the government, it usually takes a lot and soon develops a dependency.

Although the special coerciveness of the fund termination sanction makes the weapon attractive, it is also a source of concern. In many respects fund termination is like a hydrogen bomb-it is better suited to threats than to actual use. The hesitancy to inflict the sanction stems, not so much from the devastating impact that it would have on the potential recipient (who is deemed a discriminator), as from the harm that the penalty would inflict upon the intended beneficiaries of the funds, who more often than not are members of a group protected by the antidiscrimination laws. For example, the actual denial of federal financial assistance to a rural southern school system that, notwithstanding earlier threats, has refused to desegregate, would leave the schools segregated, and would hurt Black children in that district as much as anyone else, if not more. At best, the cutoff would serve as a warning to other districts. Techniques may be devised to avoid actual imposition of the sanction-for example, a suit to compel compliance with the recipient's promise not to discriminate-but they will have to be used sparingly. Frequent reliance upon these techniques may impair the credibility, and thus the potency, of the threat to use the sanction.

The special coerciveness also confines the sanction to a limited range of tasks. It was ideally suited to the 1965 enforcement efforts against southern school districts that were still operating in open defiance of Brown v. Board of Education. The principal task in those circumstances was to obtain from the school districts a commitment on paper that they would honor Brown and begin to desegregate. This initial step involved no serious factual disputes or delicate issues of law, and the crude but powerful sanction was appropriate.

Since then, however, the law enforcement task has changed from obtaining paper compliance to assuring performance, that is, assuring that the recipient is actually not discriminating; the fund termination sanction is less attractive in that context. There are likely to be intense factual and legal disputes, and few have suggested entrusting these disputes to an administrative agency without staying the sanction until judicial review is completed. Yet, if a healthy measure of judicial review is built into fund termination, the sanction loses its edge. It ceases to be a distinctive law enforcement technique and becomes merely another mold for litigation.

44 But see Board of Pub. Instruction v. Finch, 414 F.2d 1068 (5th Cir. 1969), holding that the government may terminate funds under Title VI from only those specific federal programs that are affected by discriminatory practices. 
2. Statutory Invalidation. The second major departure from the litigation model occurred when, in the Voting Rights Act of 1965, Congress invalidated state voter qualification laws, such as those imposing literacy tests. ${ }^{45}$ The theory of invalidation had its roots in Louisiana $v$. United States, ${ }^{46}$ a case in which the Supreme Court invalidated a state literacy test statute on two grounds. First, the statute vested excessive discretion in registrars, who were likely to use it in a discriminatory fashion. Second, the tests had not been applied in the past to White voters. Thus, evenhanded prospective application of the standard had left one racial class exempted-a class consisting only of Whites, due to past discriminatory practices of voting registrars. Both theories were used by Congress in the Voting Rights Act, which followed swiftly on the heels of the Supreme Court decision and the dramatic events in Selma in the spring of 1965.

But the Voting Rights Act involved more than legislative adoption of a judicially created doctrine. Because the invalidation occurred in the legislative forum, the required proof (that the discretion was likely to be abused and that Whites had been exempted in the past) was much less rigorous than the showing that any court would have required. Moreover, because a legislature rather than a court had acted, the invalidation immediately reached beyond a single county, and even be-

45 See Act of August 6, 1965, Pub. L. No. 89-110, 79 Stat. 437 (codified at 42 U.S.C. $\$ \$ 1971,1973(1970)$ ). In addition to the Act's main provisions, which suspend the operation of certain existing election laws, section 5 has introduced another law enforcement technique. It bans all new election laws in the covered states, except for proposed changes that are cleared by the Attorney General or the District Court for the District of Columbia. In such a proceeding, the locality has the burden of proving that the proposed law is nondiscriminatory.

The novelty of this clearance procedure was evidenced by Justice Black's sharp dissent in South Carolina v. Katzenbach, 383 U.S. 301, 356-62 (1966). At first, the device was used infrequently, perhaps because of the cloud Justice Black had cast over it. By July, 1969, four years after the enactment, the Attorney General had reviewed only 345 submissions and he had disapproved only ten (six of which were disapproved in 1969). S. Pollak, Effective Anti-Discrimination Legislation: An Analysis of the Voting Rights Act of 1965, at 19 (May 1, 1969) (unpublished paper on file with The University of Chicago Law Review).

Starting with Allen v. State Board of Elections, 393 U.S. 544 (decided in March, 1969), the Supreme Court construed section 5 expansively, so as to enlarge the category of election laws the statute embraced. The clearance provision was continued in the 1970 extension of the Voting Rights Act and has continued to receive supportive interpretations in the Supreme Court. See Georgia v. United States, 411 U.S. 526 (1973); Perkins v. Matthews, 400 U.S. 379 (1971). The technique has been used more frequently in the last few years of the second decade. In 1971, there were 1339 submissions and 63 objections; for 1972, 1010 submissions and 50 objections; and for 1973, 836 submissions and 32 objections. Pollak, supra at 22.

46380 U.S. 145 (1965), aff'g 225 F. Supp. 353 (E.D. La. 1963) (three-judge court). 
yond a single state; indeed, it had been tailored to have regional application. And, five years later, when the time came to review the invalidation or suspension of the state literacy test statutes, Congress broadened the law to have a nationwide reach. ${ }^{47}$ This achievement of the Voting Rights Act cannot be minimized by comparing it to judicial declarations of invalidity such as Brown v. Board of Education; for, as Professor Bickel has argued, Brown itself had not imposed a "legal obligation" (in the positivistic sense-that is, amenability to the contempt sanction) upon all dual school districts. ${ }^{48}$ Moreover, the state statutes invalidated by the Act were not deemed invalid on their face.

It seems to me, however, that this law enforcement technique has even less general applicability than the fund termination sanction, both in the antidiscrimination area and elsewhere. First, although the Voting Rights Act is generally considered extremely successful, that assessment is valid only if the goal is viewed as one of increasing the registration of Blacks. If, on the other hand, the Act's purpose is to overcome racial discrimination, past or present, its results can be criticized as overkill. And although overkill is not particularly worrisome with respect to voting rights, because of the widespread belief that the more people who are registered the better off we are, the blunderbuss of legislative invalidation could be faulted more readily if the opportunities being extended to Blacks were more scarce, as is true in employment. ${ }^{49}$

Second, although the literacy tests were not deemed invalid on their face, there was deep suspicion when the Act was passed that the defect was more structural than the abuse-of-discretion and implied-exemption theories of Louisiana $v$. United States would have suggested. That suspicion stemmed in part from the view that literacy statutes were invalid because they perpetuated the discriminatory effects of dual school systems. Although this theory was not an explicit predicate for the 1965 Act, it was in the air at the time; indeed, the Court used it in 1969 to forbid the reinstitution of literacy tests ${ }^{50}$ and again in 1970 to permit extension of the Voting Rights Act to the entire nation. ${ }^{51}$

47 Voting Rights Act Amendments of 1970 \$ 201, 42 U.S.C. \$ 1973b (1970).

48 Bickel, Discrimination in Education, in Discrmmination AND THE LAW 54-56 (V. Countryman ed. 1965).

49 Increasing the size of the electorate does not disenfranchise others but only dilutes their "voting strength," which may be crudely defined as the fraction of the total number of votes that each individual's vote represents. Of course, the right to vote also has a personal dimension; it represents the opportunity to participate in the nation's self-government. In this respect, the franchise is infinitely elastic; there is no condition of scarcity at all.

50 Gaston County v. United States, 395 U.S. 285 (1969).

51 Oregon v. Mitchell, 400 U.S. 112 (1970). 
Moreover, apart from the question of discrimination, there were doubts about the appropriateness of literacy qualifications under any circumstances. Increased use of radio and television in political campaigns created doubts about the rationality of a literacy test, and emerging case law emphasizing the precious nature of the right to vote had a similar effect.52 Once again, this theory was not a formal predicate for the Voting Rights Act of 1965, but I feel confident that it played a role in the intellectual milieu.

Third, it must be remembered that statutory invalidation occurred only after an extensive litigation program. From 1957 to 1965 the Department of Justice concentrated almost all of its civil rights resources on voting rights litigation. The program educated both judges and legislators about the effects of these state statutes; and this, perhaps above all, permitted Congress to act without the formal fact-finding that usually precedes major legislative action. Although this litigation program could conceivably be duplicated in other areas to make the legislative invalidation technique available again, the cost of preparing the soil is a considerable one and is likely to limit the availability of the technique.

\section{Statistics as an Enforcement Technique}

Thus far I have pointed to fund termination and legislative invalidation as the two major innovations in antidiscrimination law enforcement techniques during the decade 1964 to 1974. Another radical change, more doctrinal in nature, is the legitimation of measuring compliance in terms of numbers.

Racial discrimination, to use the original example, is reflected in demographic patterns. If a school board assigns students to schools on the basis of race with an eye towards promoting segregation, the result will be two sets of schools, one populated only by White students and the other only by Black students. If an employer discriminates on the basis of race with an eye towards limiting the number of Black employees, there will be few or no Black employees in his work force. If a landlord refuses to rent to Blacks, his tenants will be White. Officials charged with enforcing an antidiscrimination law can thus infer the existence of the forbidden discrimination, in this instance racial discrimination, from the demographic patterns. Sometimes, when the decision maker purports to base his decision on objective, quantifiable criteria, such as time of application, performance on standardized tests, or geography,

52 Lassiter v. Northhampton County Bd. of Educ., 360 U.S. 45 (1959), a unanimous opinion by Mr. Justice Douglas holding that literacy tests were not unconstitutional in themselves, remained on the books, but it lacked sufficient vitality to quell these doubts. 
there are alternative techniques for detecting and proving racial discrimination, for example, comparing the performance of the successful White candidates with that of the unsuccessful Blacks. But the conditions necessary for the comparison method (i.e., quantifiable selection criteria and racial identification of the applicants) are not always present; even when they are, racial statistics are often preferred because they permit cheaper and more efficient law enforcement.

During the second decade, as attention shifted away from the coverage question and open defiance came to an end, law enforcement agencies found that they were under increasing pressure to secure performance. The need for more effective and more efficient enforcement techniques became paramount. Starting with the HEW school desegregation guidelines of 1965, racial statistics were used to trigger investigations, to shift burdens of proof, and even, as with the Philadelphia Plan, to define the terms of compliance for alleged discriminators. Today, racial identification on applications for employment is permissible and sometimes required-a radical change from what we generally thought necessary to enforce fair employment laws when religious minorities were viewed as the primary beneficiaries. Since the decision maker knows an applicant's race, the racial identification merely conveys that information to the law enforcement agency.

I should emphasize, however, that although statistics pertaining to race and sex are universally employed by law enforcement agencies and although this practice has been legitimated by the courts, there is still an uneasiness about its use. The first source of this uneasiness is the fact that, although the demographic patterns may stem from racial discrimination, they may also have more innocent causes. For example, the school may be segregated because of racial assignment, or, alternatively, given the residential pattern of numerous communities, because of geographical assignment. A company may have an all White staff because of racial discrimination, or, alternatively, because there were no Black job applicants, or none with the requisite skills and talents. The apartment house may have only White tenants because of racial discrimination, or, alternatively, because of rent levels or the location of the building in relation to employment opportunities for Blacks.

The very existence of these alternative explanations raises questions about the fairness of the use of racial statistics and requires that, at the very least, the alleged discriminator must have an opportunity to show that the demographic pattern is not due to racial discrimination. That opportunity formally recognizes that alternative causes are possible and that the law is aimed at prohibiting only one possible cause, racial discrimination. But in practice the opportunity is sometimes so severely 
limited that the logical distinction between cause and consequence ceases to be of any genuine import.

A second source of uneasiness with the "numbers game" is the fear that too heavy a reliance upon statistics will create pressures or incentives for the decision maker to engage in reverse discrimination. This would occur when two factors are present. First, the authorities devote their efforts to protecting the primary beneficiaries of the antidiscrimination laws. This means that statistics are cast in terms of a characteristic (such as blackness or femaleness) that, without the antidiscrimination laws, would probably be used to the disadvantage of primary beneficiaries. Second, a condition of scarcity exists (as is true with employment and higher education opportunities, less true with voting rights, ${ }^{, 3}$ and least true with public school assignment ${ }^{54}$ ). When there is scarcity, a preference for primary beneficiaries will necessarily deny opportunities to those not possessing the ordinarily disadvantaging characteristic. This denial can be conceptualized as a form of reverse discrimination.

The charge of reverse discrimination cannot be lightly dismissed. Usually the antidiscrimination law is worded in terms general enough to embrace the dominant group (the forbidden criterion is not "blackness" but "race," not "femaleness" but "sex"); thus, reverse discrimination may violate the statute.

In addition, the violation may be more than a technical one. It is true that discrimination in favor of Blacks does not possess the element of insult that is inherent in the ordinary case of discrimination against Blacks. The discrimination is done with regret; it is devoid of any animus against the excluded individuals. And the excluded group does not even have an identity, being merely an amalgam of all groups that do not possess the characteristic that the law enforcement officials favor. Nevertheless, the unfairness to the excluded individual is perhaps no different from the unfairness of "traditional" discrimination. The applicant still has a grievance. In this context, the discrimination results from a two-step process whereby someone else is preferred because of his color (due to the efforts of enforcement agencies) and others are rejected because no more opportunities are available-rather than a one-step process whereby a person is rejected because his color is offensive. In both instances rejection is based on a characteristic that is unrelated to performance. The applicant naturally views this characteristic as inappropriate for choosing among the contenders, and the enforce-

53 See note 49 supra.

64 The point about school assignments assumes that all the schools in a single district are roughly equivalent. Perhaps due to the influence of the separate-but-equal doctrine, the courts usually do make this assumption. 
ment agency, which is using numbers as an enforcement technique, would probably concede that the rejected applicant is right.

The pressure on the decision maker to engage in reverse discrimination is mitigated if the decision maker is required to reach the same result that would be present without discrimination. He can then choose applicants or assign students on the basis of permissible criteria and let the numbers take care of themselves. But there are enormous difficulties in choosing the target statistical result with any degree of confidence, assuming that we want to withdraw from decision making only the explicitly racial factor. Too many other variables determine demographic patterns. A law enforcement agency concerned about the risk of reverse discrimination is likely either to set the statistical norm on the low side or to tolerate significant departures from the norm. That alternative is equally unsatisfying and equally susceptible to strong criticism, for it means that many discriminators will escape the net-the antidiscrimination laws will be underenforced.

\section{The Meaning of the Law-The Movement Towards a Result-Oriented Approach}

Thus far I have pointed to the changes of the second post-Brown decade in the reach of the antidiscrimination laws and in the techniques for enforcing them. In so doing, I have assumed that there was little ambiguity in the meaning of these laws. But the events of the decade call that assumption into question.

Antidiscrimination laws are capable of two basic interpretations. One interpretation-call it process-oriented-emphasizes the purification of the decisional process. The prohibition against discrimination is interpreted as a ban against basing a decision on certain forbidden criteria, for example, an individual's race. A second interpretation-call it result-oriented-emphasizes the achievement of a certain result, improvement of the economic and social position of the protected group. For example, under the result-oriented approach, the obligation imposed by the antidiscrimination laws in public education and housing is not to refrain from racial assignment but rather to achieve racial integration. Under a fair employment law the obligation is not to refrain from taking an applicant's race into consideration but rather to eliminate Black unemployment and underemployment.

There is nothing inherently antagonistic in the two interpretations. As a logical matter, it is possible that refraining from making a choice on the basis of race will improve the economic and social position of the protected group. But it is equally possible that full compliance with 
an antidiscrimination law under a process-oriented approach will not produce the desired results. A school district may assign students on the basis of nonracial criteria and yet wind up with Blacks in one school and Whites in another. Employers may hire purely on the basis of merit and yet perpetuate the income gap between Whites and Blacks. Houses may be sold and apartments rented without regard to race and at the same time patterns of residential segregation may remain intact.

A decade ago the possibility of a divergence between the processoriented and the result-oriented approach to antidiscrimination laws was perceived by some commentators. This insight did not play an important role in our thinking-either because we were preoccupied with the problems of extending coverage and ending open defiance, or because we believed or hoped that the divergence would never materialize. Now the divergence has materialized, particularly with respect to Blacks, the very group that received the major share of antidiscrimination attention during this decade. There has been integration in the sense that some Black students are going to school with Whites, but a large number of Black students-perhaps the bulk of them-are still attending schools that are predominantly, if not exclusively, Black. There has been upward economic mobility for some Blacks, but disproportionate Black unemployment and underemployment persist. There are some Blacks living in formerly all White neighborhoods, including some suburbs, but most Blacks still live in all Black neighborhoods.

We have also had enough experience with the enforcement of antidiscrimination laws to know that the all Black school, Black unemployment and underemployment, and the ghetto are not going to disappear in the near future if we remain committed to a process-oriented approach. The conclusion to be drawn is not that we have "achieved full compliance" with process-oriented antidiscrimination laws and that they have "failed." Perhaps these patterns would be eliminated if we were to let the process-oriented approach run its course for another generation or two. But I doubt that we have, or should have, so much patience. There is instead a natural temptation to move towards the result-oriented approach, viewing the aim of an antidiscrimination law in more pragmatic and immediate terms.

Yet three factors restrain the courts from wholeheartedly embracing the result-oriented approach. The first is semantic. Most antidiscriminatory laws prohibit discrimination on the basis of a criterion, such as race; they do not mention results. ${ }^{55}$ To square them with the result-

55 The one notable exception is the equal protection clause, which is worded in more 
oriented approach one must first decide on a set of "purposes" or "goals" for antidiscrimination policy, attribute them to the law, and then argue that these "purposes" or "goals" control the interpretation of the law, even to the point of overriding the language. Obviously each step of this process is fraught with difficulty; but only then could one coherently treat a seemingly innocent criterion of decision making as though it were one of the criteria proscribed in the statute.

Second, fear of reverse discrimination lessens support for the resultoriented approach. The result-oriented approach can give rise to this claim even when a seemingly innocent criterion (for instance, a standardized test) is invalidated, because people who would have benefitted from the use of that criterion lose their competitive edge. It also can give rise to this claim by leading to racial preferences-first permitting them, and then requiring them. One could logically conceive of a result-oriented approach in a situation where scarcity predominates and where choices are not made on the basis of race. For example, one could forbid companies to use certain seemingly innocent employment criteria that tend to keep Blacks in subordinate positions in a company, and then, by way of remedy, require them to award jobs on a random basis. But once a person finds himself unwilling to accept a certain result, namely, the present economic and social position of Blacks, the next step-giving preference to Blacks because of their color-seems comparatively small. ${ }^{56}$ The same impulse that leads one to invalidate the facially innocent criterion is likely to create pressure to tolerate or even require racial preferences.

This risk of reverse discrimination tends to impede, though perhaps not preclude, movement towards a result-oriented approach. A court will, of course, be reluctant to construe a statute in a way that obligates an individual to act in a manner that might itself violate the statute. Indeed, there is the further risk that if a law is construed to obligate an individual to engage in discrimination, that law might violate the equal protection guarantees of the Constitution. All these risks can be run when the goal is worthy enough, but here the worthiness remains to be seen.

Third, there is uncertainty about the desirability of the goals of the result-oriented approach. Under a process-oriented approach, integration or redistribution of wealth may occur, but they do not require

general terms and thus might be more easily read as imposing a result-oriented obligation. See text and note at note 19 supra.

56 This reasoning is illustrated by the analysis in Carter v. Gallagher, 452 F.2d 327 (8th Cir. 1972) (en banc), modifying 452 F.2d 315 (8th Cir. 1971). See also Nagel, Equal Treatment and Compensatory Education, 2 Prit. \& Pub. AFrs. 348 (1973). 
ethical justification because they are only incidental consequences of compliance. Instead, what must be justified is the purification of the process, and on that score there is a convincing argument in terms of the unfairness of judging a person on the basis of a criterion-for example, the color black-that is unrelated to future performance and likely to be perceived as a stigma of inferiority. Under a result-oriented approach, however, the results themselves must be justified, and that is a difficult task.

In the employment area, for example, the result-oriented approach defines the law's goal as redistribution of wealth from the advantaged, for example, Whites or males, to the disadvantaged, for example, Blacks or females. The most persuasive justification for this goal regards the redistribution as a form of compensation for past wrongs. ${ }^{57}$ But even that theory is far from satisfactory: the redistribution in favor of certain victim groups (Blacks, females) may be at the expense of other wronged groups (Chicanos, Puerto Ricans, religious minorities); the burden may fall upon members of the dominant group who cannot in the remotest sense be identified as past discriminators; and the beneficiaries of the redistribution may not be actual victims of those past wrongs.

Similarly, there is uncertainty as to the desirability of the postulated goal in education and housing-integration. The strongest doubts center on the goal of racial integration-ironically enough, a goal that has traditionally been central to the antidiscrimination cause, and that probably accounts for the emergence of the very idea of integration. The counterstrategy today is either to reject the idea of integration altogether, or to urge that the goal of racial integration be supplanted by a goal of economic integration-a goal that does not necessarily entail racial integration (one can exist without the other) and that may be harder to achieve than racial integration. ${ }^{58}$

It is also significant that the doubts about the value of racial integration have grown so recently, for much more is expected from that goal

57 The redistribution may also be justified in instrumental terms (for example, as a means of reducing social dissension) or as a form of collective indemnification. The latter theory is suggested by the practice in postwar Germany of having an entire community contribute to a fund to pay those who had suffered bombing losses. Regardless of who is at fault for the present position of Blacks, the polity as a collectivity could-perhaps out of simple regard for the well-being of others-assume the responsibility of helping them. In a sense, slavery would be viewed as equivalent to the accident of war.

58 In housing, the rich and the poor will not live together without heavy subsidization of one group or the other. The rich need the subsidy as an inducement to move near the poor, and the poor need a subsidy, probably a heavy one, so that they can afford to move near the rich. In education, assigning students according to economic status seems to pose more bewildering administrative problems than assigning them by race-making the prospect almost hopeless. 
today. At the outset of the decade, racial integration was defined as getting Blacks into White schools or White neighborhoods. This access component of the integration goal coincided with the goal of enlarging Blacks' range of options, so that they could attend a White school or live in a White neighborhood if they wished. Today the integration goal is linked with another task-eliminating the all Black school or the all Black neighborhood. This dispersal component is the integration goal's more costly aspect; it entails either forcing Whites into Black institutions or simply liquidating the all Black institutions-for example, closing the all Black schools and busing Black children to traditionally White schools, or clearing ("renewing") Black neighborhoods.

One source of disaffection with racial integration has been the state of social science data. The evidence to document the value of integration is thin, ${ }^{59}$ and it is particularly disappointing when we consider it in light of the heavy costs of the dispersal component. Those who believed at the beginning of the decade that integrated education would close the education achievement gap between Blacks and Whites - the aim most closely related to the ideal of equality-have waited for reassuring data from the social scientists; but the word has not come, and it is embarrassing to continue to use time as an excuse.

Another source of the growing uncertainty about the value of integration has been the emergence of Black nationalism during the second decade. In the early 1960s there were claims that the NAACP Legal Defense Fund did not speak for the entire Black community when it spoke in support of integration. But these doubts were quickly brushed aside as obstructive speculation. Over the last decade, however, Blacks began to assert these claims themselves. And not all of the separatist assertions, perhaps not even most, could be dismissed as mere defensive reactions to the failure to achieve integration. Instead, many seemed to represent genuine claims of cultural pluralism and self-determinationclaims that Americans have generally honored when other groups have voiced them.

Despite these theoretical difficulties with a result-oriented approach, the Supreme Court has taken giant strides in that direction, all in the last five years. In education, the step was Swann v. Charlotte-Mecklen-

50 See J. Coleman, Equaltry of Educatronal Opportunity (1966). Compare Pettigrew, Useem, Normandy \& Smith, Busing: A Review of "The Evidence," The Public INTERest, Winter, 1973, at 88, with Armor, The Evidence on Busing, The PUBLIC INTEREST, Summer, 1972, at 90. One response to the paucity of social science data has been to construct alternative theories to justify the same goal, for example, justifying integration as a means to bring about equal distribution of resources among the schools of a district. 
burg Board of Education. ${ }^{60}$ The Court held that a school board had not fulfilled its constitutional obligation to establish a unitary school system even though it assigned students on the basis of geographical criteria. In voting rights, the step was Gaston County $v$. United States, ${ }^{61}$ in which the Court held that evenhanded application of literacy tests would not satisfy the antidiscrimination obligation. In employment, the step was Griggs v. Duke Power Company, ${ }^{62}$ where the Court held that a company had not fulfilled its fair employment obligation even though it had hired and promoted on the basis of performance on a standardized test.

While the differences among these cases are important, a common element seems to predominate: the reasoning by which the Court justified its movement towards the result-oriented approach. In each instance, the Court traced the result to acts of discrimination in the past, and rested its finding of illegality on that ground. In Gaston County and Griggs, the court outlawed facially innocent criteria-voting tests and employment tests that had a differential impact on the two racial groups-because they perpetuated the past discrimination of the dual school system. In Swann, the Court held that a geographical criterion was an unacceptable method of student assignment because the school board's past discrimination-maintenance of a dual school system-was presumably responsible for the present segregated residential patterns of the community. These residential patterns, when combined with geographical student assignment criteria, resulted in all-Black schools. The opinions in Gaston County, Griggs, and Swann thus make the concept of past discrimination central in our present thinking about racea most important change during the past decade. During the first decade, there was hardly a trace of this concept.

The use of the concept of past discrimination is understandable. Uncertainty about the ethical foundation of a result-oriented approach can, to some degree, be circumvented by tracing the undesired result back to a process that is concededly impure. The causal explanation fills the ethical gap. ${ }^{33}$ One cannot deny that there is some linkage between the undesired results and the past discrimination, nor that the legal

60402 U.S. 1 (1971). This step was buttressed by Keyes v. School District No. 1, 413 U.S. 189 (1973). The progression may have been stopped in Milliken v. Bradley, 94 S. Ct. 3112 (1974).

61395 U.S. 285 (1969).

62401 U.S. 424 (1971).

68 It also tends to obscure the semantic problem, for conduct that "perpetuates discrimination" is easily viewed as discriminatory. 
system certainly should be able to provide a remedy-some remedyfor past wrongs against the racial class.

Nevertheless, four considerations prompt me to question whether the Court is giving too big a task to the concept of past discrimination. First, the ethical void still exists when the cost of the remedy is placed on those who were neither perpetrators nor beneficiaries of the past wrongful conduct. It may, for example, be unfair to hold an employer accountable for past discrimination in a realm totally divorced from his control, such as a public school system. Second, under the past discrimination analysis, the identity between the victim of the discrimination and the beneficiary of judicial action tends to disintegrate; to the extent that it does, the ethical basis of the beneficiary's claim loses force. Third, the causal connection between past discrimination and present results may be significantly more tenuous than what the courts declare it to be. There is a heavy reliance on presumptions--presumptions that formally, but not practically, permit a rebuttal. For example, the dual school system might have played a role in causing the segregated residential pattern of a community or the poor performance of Blacks on voter qualification or employment tests; but the evidence compels none of these connections. Difficult as it is for the alleged victims to prove any of these connections, it is equally as difficult for the alleged discriminators to prove the opposite. The concept of past discrimination has led us to rely on an odd species of empirical propositions-ones that cannot be proved or disproved. Fourth, courts do not limit the remedy in these cases to eliminating the portion of the undesired result that they can in all fairness attribute to past discrimination. A judicial conclusion that there is some causal connection between the past discrimination and a portion of the undesired result is used as a triggering mechanism-the predicate for an order eliminating the entire undesired result.

Although these problems with the past discrimination concept should not preclude its use altogether, they do indicate that reliance on the concept should be limited and hesitant. It is important to recognize not only that the process-oriented approach and the result-oriented approach diverge and that over the second decade the Court has moved us closer to the result-oriented approach, but also that this journey is proceeding along a staircase that has some deep cracks.

\section{The Nonchanges}

I have stressed the changes that have occurred in the past decadethe extension in the reach of the law, innovation in law enforcement techniques, and the movement towards a result-oriented approach in 
defining the obligations imposed by law. And there may be others, such as the changes in language-the movement from "Negro" to "Black." Of course, the practical import of these changes for the political, economic, and social position of the principal beneficiaries of the antidiscrimination laws is still uncertain; but purely as formal changes within the legal system they are striking-especially given the fact that so many important changes in the legal system have occurred within so short a time span.

Despite my emphasis upon changes, I think it is important to point to two factors that have not changed during this period; these nonchanges also define our present position. The first is that throughout this period we have used the same legal instrument, antidiscrimination law, for purposes of protecting Blacks and other groups. The nature of the legal instrument remains constant regardless of which group it protects, what activity it governs, and whether the prohibition takes statutory or constitutional form (courts use precedents interchangeably when construing statutory and constitutional antidiscrimination laws).

With respect to one of the new groups, the poor, we have adopted other beneficial strategies-direct payments in cash (for example, welfare) and benefits in kind (for example, public housing). Professor Michelman has argued that, even where we use the equal protection clause on behalf of the poor, the organizing principle should be the achievement of minimum welfare rather than the prevention of discrimination. ${ }^{64}$ Although it is difficult to give specific content to the concept of "minimum welfare," the proposal reflects an understanding of the need to move beyond or away from the antidiscrimination bind, at least with respect to the poor. The same insight has not been reflected in thinking about the protection of groups such as women and Blacks. We just cannot get away from the idea of discrimination, and I suspect that we are trying to do too much with it. ${ }^{65}$

In 1969 the demand for Black reparations surfaced, and it was abruptly pushed aside. Within the past year, Professor Bittker has written on the subject, with the avowed purpose of making the demand worthy of future discussion and debate. ${ }^{66}$ In order to do that, he finds it necessary to alter the predicate of the payment. Reparations would be given not as compensation for the exploitation of slavery, but rather as

64 Michelman, Foreword: On Protecting the Poor Through the Fourteenth Amendment, 83 HARV. L. REv. 7, 9 (1969).

65 Another exception to the general pattern is manpower training programs (which are not formally based on race, but which primarily affect Blacks). These programs seek to train workers without inquiring whether the participants are victims of discrimination.

66 B. BrtTker, The Gase for Black Reparations 19 (1973). 
compensation for the wrongs imposed by the dual school system. This conceptual switch would bring us back to the antidiscrimination principle. Reparations would then be comparable to a judicial or legislative damage award for past discrimination. The only differences would be matters of degree: stretching or ignoring statutes of limitation, tolerating a drastically attenuated relationship between victim and recipient (or wrongdoer and payer), and importing a new measure of damagesconceivably the income gap between Whites and Blacks.

Nor do I view the concept of "affirmative action" as a durable alternative, despite its current prominence in legal discourse. It is not fully intelligible without the concept of discrimination; the obligation to take affirmative action means "do not discriminate, plus." The "plus" may be reverse discrimination-"do not discriminate against Blacks and women, and, what's more, we would like you to discriminate in favor of them." The obligation to take affirmative action would then be inconsistent with the antidiscrimination law of which it is an adjunct. Alternatively, the "plus" may denote an emphasis upon results in general terms. But so construed the concept adds little to the antidiscrimination principle; for that principle, as we have seen, is already capable of focusing attention on results as a technique for measuring compliance and as a definition of the legal obligation imposed. There may be factors that counsel against a use of results as the measure of compliance and against a movement towards a result-oriented interpretation of the law; but it is more productive to confront those difficulties head-on than to obscure them with a buzz word. ${ }^{67}$

The other constant element during the decade has been the primacy of the judiciary. Other governmental imstitutions have played important roles, exemplified by the Voting Rights Act of 1965 and HEW's use of the fund termination sanction. But even there the courts have played an indispensable role in protecting the administrative agencies from attack, and in preparing the soil for legislative action. Heavy reliance on the judiciary was clearly justified at the outset of the decade, when antidiscrimination efforts were largely exerted to aid Blacks in a region of the country where they were disenfranchised and at a time when they lacked political power of their own in the rest of the country. But the question of reconciling judicial activism with our democratic tradition rises anew at the end of the second decade, as the

67 Part of the problem with the emphasis on results in the antidiscrimination laws is semantic, but the phrase "affirmative action" does not solve these difficulties. Where the words appear in an antidiscrimination law, such as the President's Executive Order, the obhgation is to take "affirmative action ... without regard to [the employee's] race, creed, color, or national origin." Exec. Order No. 11,246, 3 C.F.R. 339, 340 (Comp. 196465). 
protectorate expands to include women, a nonminority group, and as the Blacks are enfranchised through the Voting Rights Act and are able to exert increasing political strength in the cities. We may still wish to have the judiciary continue to play the pre-eminent role in leading us towards a result-oriented interpretation of antidiscrimination laws or a regime of preferential treatment. But if we do, we will have to find a justification for this judicial leadership that does not stress disenfranchisement or the absence of political power. In this respect, we now find ourselves in an awkward position. Success has spoiled the theories we constructed to legitimate the judicial leadership of the $1960 \mathrm{~s}$. 